\title{
PENGEMBANGAN DAYA TARIK WISATA BERBASIS MASYARAKAT DI PANTAI VATUVOU, DISTRIK LIQUISA, TIMOR LESTE
}

\author{
Cipriana Dos Santos Guterres \\ Program Studi Magister Kajian Pariwisata \\ Universitas Udayana \\ Email: cipriana.guterres@yahoo.com
}

\begin{abstract}
Vatuvou beach, located in the Village Vatuvou, Liquica District of East Timor, has the potential to be developed into a tourist attraction, but until now its potential has not fully developed yet. The aim of this study is to determine the potential of Vatuvou Beach, to know how the local community have been involved to develop Vatuvou beach, to formulate the most effective strategies to develop it has a community based tourist attraction.

The results of this study indicated that Vatuvou coastal region could be used as a tourist attraction in the District of Liquisa, because it has the existing potential such as beach panorama with sunset, black sandy beaches and under-sea wealth, availability of facilities and infrastructure to support tourism, such as water, electricity, road, telecommunication, public toilets, parking, and accommodation (but still limited). Socio-cultural potential as hospitality of the people in the village of Vatuvou, traditional activities, such as handcrafted, and rituals performed by people in the village of Vatuvou. In addition, the strategic location of the Vatuvou beach easily leads to some nearby tourist attraction, such as lake Maubara, Maubara Fort, historical buildings of Portuguese's heritage, and souvenir center. The involvement of community participation in the coastal development of Vatuvou has been through the initial proceses, namely planning stage, development and evaluation of activities that have been implemented. Through the description, it can be concluded that the strategy of tourism development of Vatuvou beach can be made by the following procedures (1) Increasing the quality and quantity of human resources in tourism, (2) Inviting foreign or local investors to the potential of the existing tourism sectors, (3) Developing
\end{abstract}


the potential of cultural as tourist attractions, and (4) Improving tourism facilities and infrastructure to support tourism activities in Vatuvou coastal areas.

Keywords: development, tourism attractions, Vatuvou Beach Timor Leste, community based tourism.

\section{Pendahuluan}

rtikel ini membahas potensi pantai Vatuvou, Distrik Liquica,
Timor Leste sebagai daya tarik wisata dengan memfokuskan uraian pada partisipasi masyarakat. Pantai Vatuvou merupakan daya tarik wisata yang terletak di Desa Vatuvou, Distrik Liquisa, Timor Leste yang mudah dijangkau dari pusat kota, jaraknya kurang lebih $17 \mathrm{~km}$ dari kota Liquica dan $61 \mathrm{~km}$ dari ibukota Dili. Desa Vatuvou Sub-Distrik Maubara Distrik Liquica memiliki berbagai potensi wisata yang terus digali dan dikembangkan sebagai modal pengembangan pariwisata berbasis pada komunitas (Community-based tourism development) dengan cara memberikan kesempatan kepada masyarakat di Desa Vatuvou Distrik Liquisa turut berpartisipasi dalam pengelolaan pariwisata di daerahnya.

Lembaga Swadaya Masyarakat Haburas Foundation telah melibatkan masyarakat lokal di Desa Vatuvou dari awal perencanaan pengembangan sampai saat ini. Haburas Foundation adalah salah satu NGO Lokal (Non Government Organization) yang ada di Timor Leste, telah mengembangkan program pariwisata berbasis masyarakat di Pantai Vatuvou Desa Vatuvou Distrik Liquisa. Haburas Foundation merealisasikan program pariwisata berbasis masyarakat bertujuan untuk penambahan sumber pendapatan masyarakat tanpa menciptakan ketergantungan pada satu usaha saja, pemerataan pendapatan masyarakat, pemberdayaan masyarakat, pelestarian budaya lokal dan mendukung pembangunan berwawasan lingkungan hidup (De Carvalho dkk, 2008).

Pantai Vatuvou memiliki panorama pantai dengan sun set 
dan hamparan pasir yang bersih dan halus, ombak yang besar baik untuk para peselancar. Pemandangan indah tersebut dapat disaksikan sepanjang perjalanan dari Dili masuk ke Liquisa, mengelilingi punggung gunung kemudian menuruni lembah. Pantainya berbatu-batu karang, seperti pantai pada umumnya di Timor Leste, terdapat sungai bersumber dari gunung yang mengalir ke laut, akan tetapi sungai tersebut sering kering pada musim kemarau.

Selain itu Pantai Vatuvou memiliki kekayaan alam bawah laut dan terumbu karang yang masih lestari. Letak Pantai Vatuvou sangat strategis dan mudah diakses ke beberapa obyek wisata terdekat, seperti danau Maubara dengan pemandangan alam yang indah dengan latar hutan tropis yang hijau dan lebat, peninggalan bersejarah, seperti benteng pertahanan bangsa Belanda yang sampai saat ini masih utuh dan beberapa bangunan tua lainnya yang ada di Distrik Liquisa Desa Vatuvou. Fasilitas yang tersedia di daerah tujuan wisata Pantai Vatuvou antara lain air bersih, listrik, kamar mandi dan toilet, telekomunikasi, akomodasi (akan tetapi masih sangat terbatas), kios cinderamata dan lain sebagainya sebagai fasilitas penunjang pariwisata, walaupun belum memenuhi standar fasilitas pariwisata.

Daya tarik wisata Pantai Vatuvou secara ekonomi mampu memberikan kontribusi positif dalam meningkatkan pendapatan masyarakat lokal karena saat ini pengelolaan daya tarik wisata dilaksanakan langsung oleh masyarakat dengan pengawasan LSM Haburas Foundation. Akan tetapi fasilitas sejak dikembangkannya Pantai Vatuvou belum terlihat adanya perubahan. Hal ini nampak pada tempat peristirahatan atau bungalow yang masih sangat terbatas dimana tidak bisa menampung wisatawan pada musimmusim liburan seperti menjelang hari raya natal dan tahun baru juga pada saat weekend.

Selain tempat peristirahatan terbatas, fasilitas yang ada di penginapan tersebut belum lengkap seperti lemari, meja. Kursi dan tempat sampah tidak tersedia di kamar, demikian pula belum adanya fasilitas-fasilitas untuk keperluan wisatawan seperti 
alat-alat menyelam (diving), tidak ada taman dan belum adanya pertunjukan didaerah tujuan wisata, seperti kesenian daerah, taritarian untuk menghibur wisatawan.

Pengembangan pantai Vatuvou belum didukung dengan strategi pengembangan yang direncanakan dengan baik, fasilitas pendukung belum memadai serta kurangnya kerjasama antara pihak pengelola dalam hal ini LSM Haburas Foundation dengan pemerintah setempat. Pengembangan daya tarik wisata tanpa didukung dengan adanya fasilitas yang memadai akan sulit untuk dikembangkan. Akibatnya Pantai Vatuvou akan kehilangan wisatawan sebelum masuk ke tahap siklus hidup daya tarik yang lebih maju, sehingga masyarakat yang telah bergantung pada sektor pariwisata akan mengalami kerugian.

Timor Leste sebagai negara baru saat ini aktif mengembangkan potensi pariwisatanya. Industri pariwisata di TimorLeste mulai terlihat mengalami perkembangan seiring dengan meningkatnya wisatawan mancanegara ke Timor Leste sekitar 4-5 tahun terakhir. Hal ini dibuktikan dari data yang dikeluarkan oleh Statistical Data National Directorate of Tourism Timor Leste pada tahun 2010 yang menunjukan bahwa angka kunjungan wisatawan asing (visitor arrival) pada tahun 2006 sebanyak 12.042 orang, sedangkan pada tahun 2010 meningkat mencapai 28.824 orang. Motivasi perjalanan para wisatawan yang datang ke Timor Leste, dengan tujuan berlibur, usaha (bisnis), mengunjungi keluarga, tugas pemerintah, dan lain-lain.

Timor Leste memiliki banyak potensi dan sumber daya alam di sektor pariwisata yang belum dikembangkan secara maksimal, sehingga perlu diupayakan pengembangan produkproduk yang mempunyai keterkaitan dengan sektor pariwisata. Salah satu daya tarik wisata yang akan dikembangkan di Timor Leste adalah Pantai Vatuvou.

\section{Pendekatan dan Metode}

Pendekatan dalam analisis artikel ini menggunakan beberapa konsep antara lain, strategi pengembangan, daya 122 JUMPA Volume 01, Nomor 01, Juli 2014 
tarik wisata dan pariwisata berbasis masyarakat. Adapun teori yang digunakan dalam artikel ini teori perencanaan dimana dalam pengembangan pariwisata harus didahului dengan perencanaan sehingga adanya pedoman pelaksanaan dan tolak ukur pencapaian tujuan pembangunan. Menurut Yoeti (dalam Rero 2011: 20) ada beberapa alasan mengapa perencanaan diperlukan: Pertama, memberi pengarahan dalam hal ini dengan perencanaan dalam suatu organisasi atau tim mengetahui apa yang hendak dilakukannya; Kedua, membimbing kerjasama maksudnya perencanaan dapat membimbing para petugas untuk tidak bekerja menurut kemauannya sendiri. Dengan adanya perencanaan, ia merasa sebagai bagian dari suatu tim; Ketiga, menciptakan koordinasi dalam hal ini bila suatu proyek masing-masing keahlian berjalan terpisah tidak akan tercapai suatu inkrenisasi dalam pelaksanaan. Karena itu sangat diperlukan adanya koordinasi; Keempat, menjamin tercapainya kemajuan yaitu dalam suatu perencanaan pada umumnya telah menggariskan suatu program yang hendak dilakukan meliputi tugas yang dikerjakan dan tanggungjawab tiap individu atau tim dalam proyek. Bila ada penyimpangan antara yang telah direncanakan dengan apa yang telah dilaksanakan, akan segera dapat dihindarkan; Kelima, untuk memperkecil resiko; karena dengan perencanaan lebih memperkecil resiko yang timbul berlebihan. Keenam, mendorong dalam pelaksanaan maksdunya untuk mencapai hasil diperlukan tindakan, untuk melakukan tindakan dibutuhkan suatu perencanaan dan program. Untuk membuat suatu perancanaan diperlukan suatu kebijaksanaan dalam mengambil keputusan. Dengan demikian untuk mengetahui data yang perlu dikumpulkan, kita memerlukan tujuan yang hendak dicapai terlebih dahulu, sedangkan untuk mencapai suatu tujuan (objectives) diperlukan suatu pemikiran (thought) yang khusus. Jadi perencanaan (planning) merupakan suatu mata rantai yang esensial antara pemikiran (thought) dan pelaksanaan (action). Sedangkan teori partisipasi dimana dalam Keberhasilan pengembangan sebuah daya tarik wisata sangat 
tergantung dari berbagai faktor. Salah satunya adalah adanya dukungan atau partisipasi masyarakat dimana daya tarik tersebut dikembangkan. Keterlibatan masyarakat dalam konteks ini mengandung pengertian bahwa pengembangan sebuah daya tarik wisata hendaknya dikembangkan dari, oleh,dan, untuk masyarakat.

Metode dan teknik pengumpulan data dengan teknik observasi, teknik wawancara dan dokumentasi. Informan terdiri dari instansi pemerintah (SEPFOPE Dili Timor Leste), LSM (Lembaga Swadaya Masyarakat) Haburas Foundation, masyarakat lokal yang terlibat langsung dalam kegiatan pariwisata, tokoh masyarakat lokal, wisatawan manca negara dan wisatawan domestik. Metode dan teknik analisis data yang digunakan adalah deskriptif kualitatif dan analisis SWOT.

\section{Pengembangan Vatuvou sebagai Daya Tarik Wisata}

Pengembangan pantai Vatuvou sebagai daya tarik wisata diarahkan pada pengelolaan yang berbasis masyarakat sehingga dapat menjadi penunjang kegiatan perekonomian masyarakat lokal. Desa Vatuvou adalah salah satu daerah yang memiliki potensi wisata beragam, yaitu obyek wisata alam, wisata budaya dan wisata belanja. Pada hari-hari libur banyak kendaraan pribadi memadati tempat wisata Maubara Desa Vatuvou. Pantai Vatuvou memiliki lokasi yang strategis dengan daya tarik wisata pendukung, antara lain Lagoa atau Danau Maubara, bangunan peninggalan Belanda berupa benteng Maubara, penjara bawah tanah serta pusat berbelanja oleh-oleh khas Desa Vatuvou Distrik Liquisa. Sarana penunjang pariwisata merupakan faktor pendukung keberhasilan pengembangan sebuah destinasi wisata. Adapun sarana dan prasarana yang tersedia di pantai Vatuvou antara lain:

\subsection{Atraksi}

Pantai Vatuvou memiliki panorama alam pantai yang eksotis dengan hamparan pasir yang bersih dan halus dan ombak 
yang menjadi daya tarik bagi wisatawan berkunjung ke Pantai Vatuvou. Mereka menghabiskan waktu dengan berjemur atau melakukan aktivitas olahraga, seperti bermain volley pantai. Para wisatawan juga bisa berenang, menyelam serta menyaksikan pesona sunset pada sore hari serta pemandangan burung laut yang terbang rendah dan sesekali menyambar ikan di sepanjang pantai. Panorama indah tersebut dapat dinikmati melalui penginapan wisata atau dari atas perahu nelayan yang berjalan perlahanlahan di tepi pantai. Selain itu Pantai Vatuvou memiliki kekayaan alam bawah laut yang tidak kalah menarik dengan keindahan laut yang ada di tempat lain di Timor Leste.

\subsection{Aksesibilitas}

Aksesibilitas menuju ke pantai Vatuvou berupa jalanan aspal yang cukup lebar dan memadai. Jalan ini dapat dilalui dengan menggunakan kendaraan pribadi, angkutan umum dalam kota maupun angkutan umum (bus) antar distrik/ kabupaten dan bus atau travel antara Dili dan Kupang. Aksesibilitas untuk menuju ke lokasi pantai Vatuvou sangat mudah dan lancar karena jarak pencapaian dari pusat kota tidak terlalu jauh, hanya ditempuh dengan waktu 15 menit dari kota Liquisa dan dari Ibukota Dili \pm 35 menit. Di lokasi pantai Vatuvou tersedia pula areal parkir oleh pengelola bagi pengunjung yang datang ke tempat wisata Pantai Vatuvou. Areal parkir tersebut memiliki daya tampung yang cukup luas untuk kendaraan baik roda dua maupun roda empat. Selain itu, keamanan juga terjamin. Kendaraan yang parkir di tempat tersebut aman dan terlindung dari panas matahari karena ada tanaman peneduh.

\subsection{Fasilitas Penunjang Pariwisata}

Sarana pariwisata yang telah tersedia di lokasi Pantai Vatuvou antara lain penyediaan air bersih, kebutuhan air bersih penduduk Vatuvou pada umumnya di peroleh dari jaringan PAM (Perusahaan Air Minum). Namun, pada musim kemarau masyarakat menggunakan air dari sumur dan pompa air, karena 
pada musim tersebut pasokan air bersih berkurang dan hanya digunakan untuk masak dan minum, tidak untuk keperluan lain, seperti mencuci dan mandi. Adapun listrik yang tersedia di Desa Vatuvou berasal dari pembangkit tenaga diesel yang dibangun oleh Pemerintah Timor Leste. Sumber daya listrik tersebut dimanfaatkan dengan baik, selain untuk memenuhi kebutuhan rumah tangga, juga dimanfaatkan untuk memenuhi keperluan wisatawan yang menginap di penginapan di pantai Vatuvou.

Di Desa Vatuvou hanya terdapat satu bungalow dan juga restoran yang memiliki akses langsung dengan pantai Vatuvou. Bungalow tersebut berbentuk rumah tradisional Timor Leste yang sederhana. Pantai Vatuvou memiliki fasilitas umum berupa kamar mandi yang cukup sederhana. Masyarakat yang mengelola fasilitas umum tersebut menjaga kebersihan dan memeriksa ketersediaan air bersih serta tissue dan sabun. Terdapat pula fasilitas penunjang pariwisata yang lain, seperti kios cinderamata. Membeli cinderamata (souvenir) merupakan salah satu aktifitas wisatawan di sana. Mereka membutuhkan cinderamata untuk kenang-kenangan ataupun untuk diberikan kepada keluarga dan teman-temannya. Perjalanan para turis ke Timor Leste, selain menikmati keindahan alam Timor Leste, juga mencari cinderamata. Timor Leste terkenal dengan berbagai cinderamata yang khas, seperti kain Tais dalam bentuk tas, dompet, dan sepatu. Terdapat pula cinderamata lainnya berupa cincin, gelang, anting yang terbuat dari daun lontar dan merupakan kerajinan buatan masyarakat Desa Vatuvou.

Jasa-jasa pendukung wisata yang disediakan oleh pemerintah dan swasta maupun masyarakat setempat guna menunjang pengembangan pariwisata di daerah tersebut antara lain terdapat lembaga penyelenggaraan pemerintah desa yang terdiri dari kepala desa dan perangkat desa, LSM Haburas Foundation serta pelayanan pendukung lainnya, berupa layanan telekomunikasi dan kesehatan. 


\subsection{Partisipasi Masyarakat dalam Pengembangan Pantai Vatuvou}

Partisipasi merupakan sebuah proses di mana masyarakat sebagai salah satu stakeholders, terlibat mempengaruhi dan mengendalikan pembangunan di tempat mereka masing-masing. Pitana (2002: 56) mendefinisikan bahwa partisipasi tidak hanya merupakan sebuah kontribusi tenaga, waktu, dan materi lokal secara cuma-cuma, untuk mendukung berbagai program dan proyek pembangunan melainkan sebagai suatu keterlibatan secara aktif dalam setiap proses. Peran aktif yang dimaksud adalah mulai dari perencanaan, penentuan rancangan, pelaksanaan sampai dengan pengawasan dan penikmatan hasilnya atau dengan kata lain masyarakat lokal sebagai pelaku pariwisata.

Dalam pengembangan Pantai Vatuvou masyarakat dilibatkan mulai dari tahap perencanaan, tahap pengembangan dan tahap evaluasi.

\subsubsection{Partisipasi Masyarakat dalam Tahap Perencanaan}

Partisipasi masyarakat lokal dalam perencanaan kegiatan pariwisata di Desa Vatuvou dari proses awal sebelum memulai pelaksanaan pengembangan kawasan pantai Vatuvou sebagai kawasan pariwisata. LSM Haburas Foundation telah melibatkan masyarakat lokal di Desa Vatuvou dari awal perencanaan sampai pelaksanaan. Pada saat memulai perencanaan, di daya tarik wisata Pantai Vatuvou telah dilakukan penyusunan rencana tahap awal melalui musyawarah partisipatif untuk merencanakan dan mengatasi masalah-masalah yang akan dirasakan oleh masyarakat dengan memanfaatkan potensi yang ada. Perumusan perencanaan disusun oleh LSM Haburas Fundation bersama-sama dengan masyarakat lokal yang ada di Desa Vatuvou.

Dalam tahap perencanaan awal dimana pengelola program melakukan kegiatan pertemuan dengan masyarakat, rapat dan identifikasi masalah yang berhubungan dengan rencana pengembangan, pembentukan kelompok Laloran Maubara yang bertujuan mendidik masyarakat Desa Vatuvou secara mandiri mengelola pantai Vatuvou dan daya tarik wisata disekitarnya. 
Kelompok ini dipimpin oleh seorang koordinator yang diangkat oleh pihak Haburas Foundation. Adapun peningkatan pengetahuan untuk masyarakat lokal tentang sektor pariwisata melalui diskusi dan pelatihan dasar seperti kursus bahasa Inggris, kursus tourist services, kursus kerajinan bambu, kursus kuliner, dan pemandu wisatawan.

Perencanaan pantai Vatuvou sebagai daya tarik wisata, pada masa yanga akan datang perlu adanya penambahan fasilitasfasilitas pariwisata yang bisa menunjang kenyamanan bagi wisatawan. Penambahan tersebut tidak hanya dari segi kuantitas tetapi juga kualitas.

\subsubsection{Partisipasi Masyarakat dalam Tahap Pengembangan}

Partisipasi masyarakat lokal Desa Vatuvou dalam menjadi pemilik dan pengelola langsung fasilitas wisata serta pelayanannya, sehingga mereka secara langsung dapat menerima keuntungan ekonomi. Pengelolaan usaha ini dijalankan dengan manajemen yang sederhana dalam suasana kekeluargaan dan berkembang secara alami tanpa adanya campur tangan dari pemerintah. Dengan demikian dapat dikatakan bahwa pengembangan pariwisata di Desa Vatuvou benar-benar berbasis pada masyarakat setempat (Community based tourism).

Bagi masyarakat lokal, terlibat secara langsung dalam pengelolaan usaha pariwisata merupakan pengalaman baru dan penuh dengan tantangan, karena mereka tidak begitu professional atau mereka tidak menempuh jalur pendidikan khususnya kepariwisataan. Namun selama ini LSM Haburas Foundation memfasilitasi dan memotivasi mereka sebagai pelaku utama dalam pengembangan daerah wisata untuk lebih memahami tentang keadaanalam danbudayanya.Pengembangan pantai Vatuvouyang dikelola oleh masyarakat lokal telah menjadikan mereka sebagai pemilik dari pembangunan pariwisata di daerahnya, antara lain bersama-sama dengan LSM Haburas Foundation menyediakan sarana akomodasi pariwisata, membuka peluang tumbuhnya usaha-usaha kecil seperti kios cinderamata yang lokasinya tidak 
jauh dari pantai Vatuvou. Mereka memasarkan hasil kerajinan tangannya untuk menunjang kehidupan ekonomi mereka. Selain itu, sikap keramah tamahan masyarakat serta kesadaran untuk menjaga kebersihan dan keamanan di daerah wisata Pantai Vatuvou menjadi faktor pendukung pengembangannya.

\subsubsection{Partisipasi Masyarakat dalam Tahap Evaluasi}

Dalam tahap ini, pihak Haburas Foundation dan masyarakat pengelola melaksanakan evaluasi kegiatan setiap akhir tahun. Tujuannya untuk membahas tentang hasil yang dicapai serta kendala yang dihadapi oleh masyarakat pengelola wisata pantai Vatuvou, serta memperbaiki dan merencanakan kegiatan yang akan datang. Evaluasi dilakukan terhadap segala aspek pengelolaan pantai Vatuvou.

Melakukan evaluasi kegiatan merupakan proses yang berlangsung terus menerus dan berkesinambungan. Evaluasi setiap kegiatan dilakukan dan berdasarkan hasil evaluasi dapat diketahui kemajuan, kendala dan capaian yang sudah dihasilkan. Dari proses evaluasi ini bisa ditemukan hal-hal baru dan strategi baru untuk mencapai sasaran dan tujuan.

\subsection{Strategi Pengembangan Pantai Vatuvou}

Pantai Vatuvou merupakan salah satu potensi wisata yang ada desa Vatuvou, distrik Liquisa. Pantai Vatuvou dapat dikembangkan menjadi daya tarik wisata, akan tetapi sampai saat ini belum dilakukan secara optimal. Oleh karena itu, perlu dilakukan identifikasi penyebabnya. Penggunaan analisis SWOT untuk mempertimbangkan dan membandingkan antara faktor internal, berupa kekuatan dan kelemahan dengan faktor eksternal, berupa peluang dan ancaman, sehingga hasil analisisnya dapat diambil suatu keputusan strategi bagi pengembangan daya tarik wisata pantai Vatuvou.

Faktorinternalyangmendukung(kekuatan)pengembangan daya tarik wisata pantai Vatuvou, antara lain potensi sumber daya alam, seperti panorama pantai dengan sunset, pantai berpasir 
hitam dengan gelombang air laut yang tinggi, kekayaan alam bawah laut dan keramahtamahan masyarakatnya. Selain itu, juga tersedia fasilitas penunjang pariwisata, seperti air bersih, listrik, toilet umum, akomodasi (akan tetapi masih terbatas), kios cinderamata, sarana komunikasi dan lain sebagainya, tetapi belum memenuhi standar fasilitas pariwisata. Selain itu, letak daya tarik wisata Pantai Vatuvou yang strategis, mudah diakses ke beberapa obyek wisata terdekat, seperti Danau atau Lagoa Maubara. Juga terdapat bangunan-bangunan peninggalan bangsa Portugis, seperti benteng Maubara, penjara bawah tanah peninggalan Belanda dan tempat belanja buah-buahan dan souvenir. Faktor pendukung lainnya, seperti keterlibatan masyarakat lokal dalam pengembangan daerah wisata pantai Vatuvou.

Faktor penghambat (kelemahan), antara lain kurangnya SDM yang memiliki kemampuan dan ketrampilan dalam bidang pariwisata, kurangnya dana untuk pengembangan daya tarik wisata pantai Vatuvou, kurangnya fasilitas penunjang pariwisata, misalnya akomodasi, belum adanya dukungan dan partisipasi dari pemerintah, kurangnya promosi mengenai DTW pantai Vatuvou, dan juga belum dikembangkannya potensi budaya sebagai daya tarik wisata.

Faktor eksternal yang mendukung (peluang) dalam pengembangan daya tarik wisata pantai Vatuvou, antara lain pertumbuhan ekonomi, adanya peningkatan minat berwisata, peningkatan hubungan kerjasama antara pelaku pariwisata dan pemerintah dalam menghasilkan sumber daya manusia yang kompeten di bidang pariwisata, keragaman budaya, dan kemajuan teknologi informasi.

Faktor penghambat (ancaman) adalah meningkatnya persaingan dengan daya tarik wisata lainnya, adanya kesamaan produk di beberapa objek yang ada di Timor Leste. Selain itu, menurunya nilai-nilai budaya karena pengaruh yang nampak dari pesatnya kegiatan pariwisata.

Strategi prioritas berdasarkan analisis SWOT adalah perlu dilakukan peningkatkan kualitas dan kuantitas SDM di bidang 
Pengembangan Daya Tarik Wisata Berbasis Masyarakat di Pantai Vatuvou...

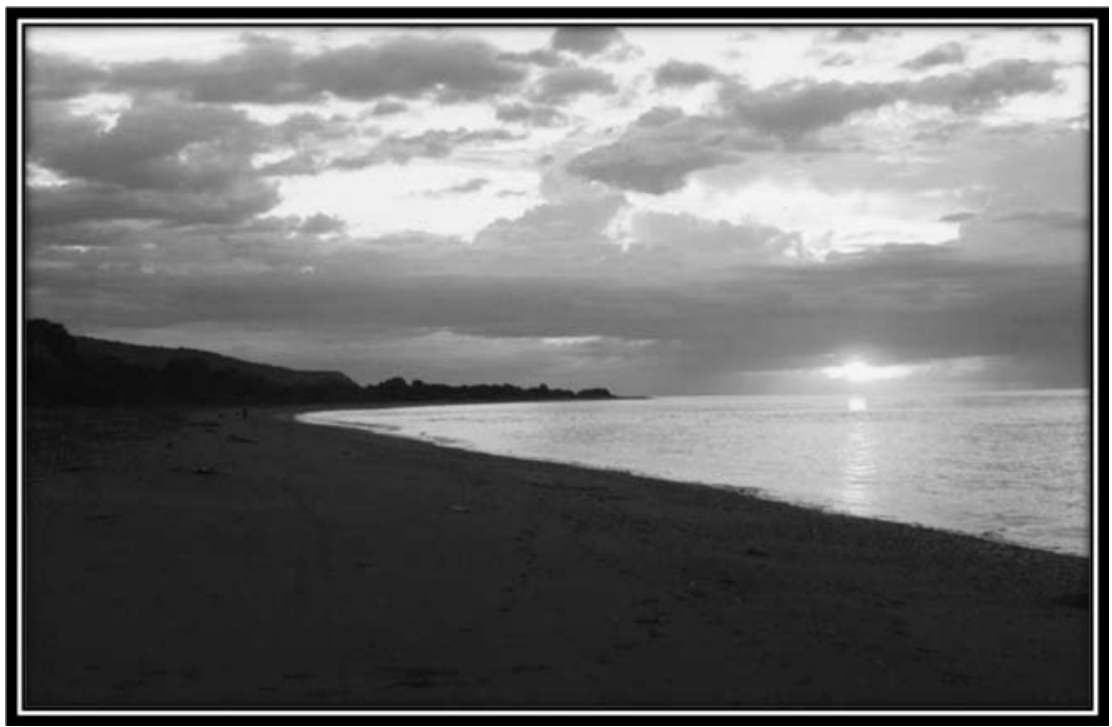

Gambar: Pantai Vatuvou pada sore hari. (Sumber: Dokumnetasi peneliti 2014)

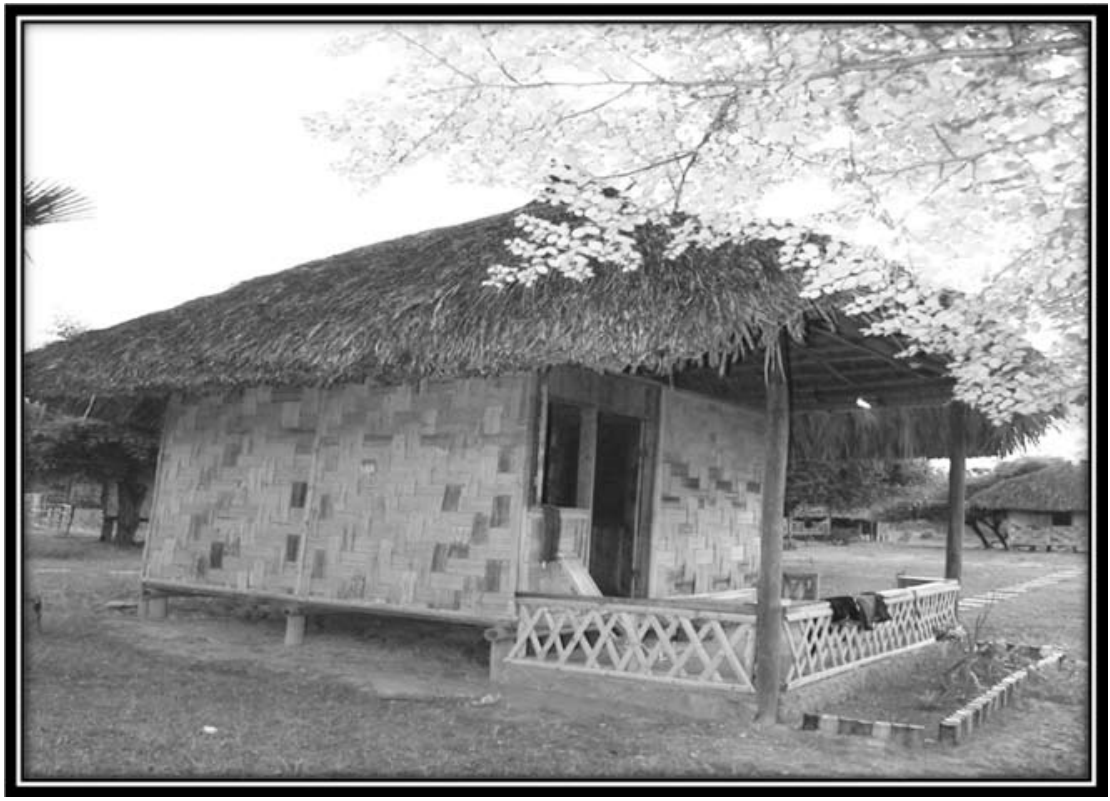

Gambar: Penginapan Laloran Maubara di Pantai Vatuvou. (Sumber: Dokumentasi Peneliti 2014). 


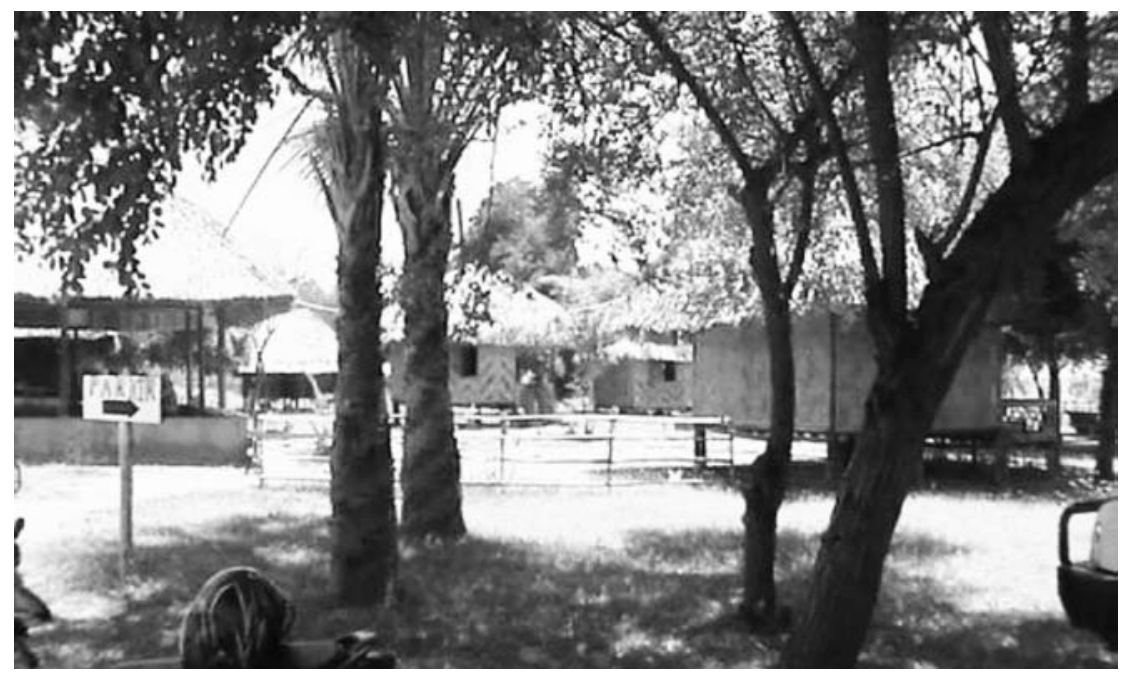

Gambar: Penginapan Laloran Maubara di Pantai Vatuvou. (Sumber Dokumentasi Peneliti 2014).

pariwisata, mengundang investor asing atau lokal untuk menggarap potensi sektor pariwisata yang ada. Peningkatan sarana dan prasarana penunjang pariwisata guna mendukung kegiatan wisata di pantai Vatuvou dan pengembangan potensi budaya.

\section{Penutup}

Berdasarkan hasil penelitian yang telah diuraikan, maka disimpulkan bahwa Desa Vatuvou memiliki potensi alam yang beragam berupa pantai yang indah dengan hamparan pasir yang bersih dan halus, ombak yang bagus untuk para peselancar, dan dapat menyaksikan pesona tenggelamnya matahari (sunset) pada sore hari, keindahan dan kekayaan alam bawah laut yang sangat menarik, di mana dapat dijumpai terumbu karang yang masih lestari.

Sekitar 300 meter dari pantai Vatuvou terdapat danau Maubara dengan pemandangan alam yang indah dengan latar hutan tropis yang hijau dan lebat, serta situs peninggalan sejarah, seperti benteng pertahanan bangsa Belanda yang sampai saat ini masih utuh dan beberapa bangunan tua lainnya yang ada di Distrik Liquisa Desa Vatuvou. Selain potensi alam juga ada 
potensi sosial budaya yang menarik wisatawan, diantaranya keramah tamahan masyarakat Desa Vatuvou, industri kerajinan, kesenian rakyat, seperti tari-tarian, misalnya tebe-tebe, bidu, dahur, upacara dan ritual adat. Budaya tersebut dapat ditampilkan untuk wisatawan yang datang ke obyek wisata Desa Vatuvou. Wisatawan asing yang berkunjung ke wisata Distrik Liquisa Desa Vatuvou lebih tertarik dengan kerajinan tangan, kesenian rakyat, seperti tarian bidu dan dahur. Pada event tertentu masyarakat selalu mempertunjukkan tarian tersebut dan para wisatawan diajak ikut menari. Selain itu, wisatawan juga merasa senang dengan sikap keramah tamahan penduduk Desa Vatuvou. Daerah wisata pantai Vatuvou didukung dengan sarana dan prasarana, antara lain air bersih, listrik, akses jalan raya, telekomunikasi, toilet umum, tempat parkir, akomodasi (namun masih terbatas).

Partisipasi masyarakat Desa Vatuvou dalam pengembangan pantai Vatuvou dimulai dari tahap perencanaan, tahap pengembangan dan tahap evaluasi kegiatan yang telah dilaksanakan. Partisipasi masyarakat dari tahap perencanaan yaitu masyarakat Desa Vatuvou telah dilibatkan dari proses awal perencanaan dan pengembangan pantai Vatuvou. Pada saat memulai perencanaan, di daya tarik wisata pantai Vatuvou, masyarakat telah dilibatkan dalam penyusunan rencana tahap awal melalui musyawarah partisipatif untuk merencanakan dan mengatasi masalah-masalah yang akan dirasakan oleh masyarakat dengan memanfaatkan potensi yang ada. Perumusan perencanaan disusun oleh LSM Haburas Fundation bersama-sama dengan masyarakat lokal yang ada di Desa Vatuvou.

Dalam tahapperencanaanawal, pengelola programmelakukan kegiatan pertemuan dengan masyarakat, rapat dan identifikasi masalah yang berhubungan dengan rencana pengembangan. Partisipasi masyarakat lokal dalam pengembangan pantai Vatuvou telah menjadikan masyarakat lokal sebagai pemilik dan pengelola dari pembangunan pariwisata di daerahnya. Masyarakat bersama-sama dengan LSM Haburas Foundation menyediakan sarana akomodasi, toilet umum, parkir, membangun akses jalan 
menuju ke obyek wisata pantai Vatuvou, menjaga keamanan, menjaga kebersihan serta menunjukan sikap keramahtamahan terhadap wisatawan yang berkunjung ke daerah tujuan wisata pantai Vatuvou.

Partisipasi masyarakat lokal dalam tahap evaluasi kegiatan pariwisata. Dalam tahap ini pihak Haburas Foundation dan masyarakat dilibatkan dalam pelaksanaan evaluasi kegiatan setiap akhir tahun bertujuan untuk membahas tentang hasil yang telah dicapai, serta kendala yang dihadapi terhadap kegiatan yang telah dilaksanakan oleh masyarakat pengelola wisata pantai Vatuvou, serta merencanakan kegiatan yang akan datang. Evaluasi keberhasilan kegiatan yang telah dicapai, yaitu Pantai Vatuvou sudah banyak dikunjungi wisatawan pada hari-hari libur, seperti hari raya Natal, baik wisatawan lokal maupun wisatawan asing. Kendalanya yaitu tidak banyak pilihan jenis makanan yang tersedia, selain itu tempat peristirahatan terbatas sehingga tidak bisa menampung wisatawan yang begitu banyak. perencanaan selanjutnya yaitu di daerah wisata pantai Vatuvou harus ditambahkan tempat peristirahatan serta penyediaan jenis makanan yang cukup bagi para wisatawan yang berkunjung ke tempat wisata tersebut.

Strategi prioritas berdasarkan SWOT adalah meningkatkan kualitas dan kuantitas SDM di bidang pariwisata, mengundang investor asing atau lokal untuk menggarap potensi sektor pariwisata yang ada, peningkatan sarana dan prasarana penunjang pariwisata guna mendukung kegiatan wisata di pantai Vatuvou serta pengembangan potensi budaya . Adapun usahausaha nyata yang berhasil dilakukan di Pantai Vatuvou, yaitu pengadaan fasilitas umum seperti parkir untuk wisatawan, akses jalan raya yang cukup memadai, penyediaan sarana akomodasi (penginapan) walaupun masih sangat terbatas, dilengkapi dengan restoran, toilet umum, listrik, telekomunikasi, serta air bersih yang disediakan oleh masyarakat pengelola.

Dengan demikian, pengembangan pariwisata di daya tarik wisata pantai Vatuvou diperlukan adanya kerjasama antara 
pemerintah, pelaku usaha wisata, dan masyarakat lokal untuk dapat meningkatkan pendapatan masyarakat serta mengurangi tingkat pengangguran.

\section{UCAPAN TERIMA KASIH}

Artikel ini merupakan ringkasan dari tesis penulis yang mendapat saran dari pembimbing dan pihak lainnya. Untuk itulah, dengan rasa setulus hati penulis menyampaikan terima kasih yang sebesar-besarnya kepada Prof. Dr. Ir. Made Antara, MS selaku Pembimbing I yang dengan kesabaran memberikan bimbingan, masukan, saran dan koreksi untuk kesempurnaan tesis penulis. Terima kasih yang sebesar-besarnya juga penulis sampaikan kepada Dr. Ir. Syamsul Alam Paturusi, MSP selaku Pembimbing II yang telah memberikan bimbingan, serta petunjuk-petunjuk mengenai isi dan teknis penulisan selama penyelesaian tesis ini. Tidak lupa juga penulis ucapkan terima kasih kepada para penguji yaitu Prof, Dr. I Nyoman Sirtha, SH.MS, Dr. I Nyoman Madiun,M.Sc., dan Prof. Dr. I Nyoman Darma Putra,M.Litt, yang telah banyak memberikan masukan, kritik dan saran serta koreksi sehingga tulisan ini berwujud seperti ini.

\section{PROFIL PENULIS}

Cipriana dos Santos Guterres L.Ed, M. Par adalah alumnus Magister Kajian Pariwisata di Universitas Udayana Denpasar tahun 2014. Ia menyelesaikan program studi S1 pada tahun 2011 di Fakultas Ilmu Pendidikan di Universitas Nasional Timor Leste. Cipriana pernah bekerja pada LSM FOKUPERS (Forum Komunikasi untuk Perempuan Timor Leste) dan pada pemberdayaan perempuan dari perspektif hak asasi manusia, serta memberikan dukungan kepada perempuan korban kekerasan rumah tangga. Dengan pertimbangan bahwa pendidikan adalah modal untuk masa depan, Cipriana menempuh pendidikan kajian pariwisata karena lulusan pariwisata di Timor Leste masih kurang, dan yang bekerja di dunia pariwisata juga masih jarang yang menempuh pendidikan formal pariwisata. Cipriana tertarik 
untuk mengembangkan pariwisata di Timor Leste karena negeri ini memiliki banyak potensi dan sumber daya alam di sektor pariwisata yang belum dikembangkan secara maksimal.

\section{DAFTAR PUSTAKA}

Alwi, H.Hans, L.Dendy,S. Dameria,N. 2007. Kamus Besar Bahasa Indonesia. Edisi Keempat. Jakarta: Balai Pustaka

Anonim, Perencanaan Pembangunan Nasional Timor Leste, Laporan Keadaan Negara Timor Leste. 2002. Pemerintah Negara Timor Leste.

Apsari, Luh Oka Puji. 2005."Studi Pengelolaan Obyek Wisata alam Bukit Jambul Secara berkelanjutan di Desa Pesaban, Kecamatan rending, Kabupaten Karangasem"(tesis).Denpasar: Universitas Udayana.

Arsana, I Ketut. 2010. “Strategi Pengembangan Kawasan Masceti Sebagai Daya Tarik Wisata Alam Berbasis Masyarakat di Desa Medahan Kecamatan Blahbatuh Kabupaten Gianyar" (Tesis). Denpasar: Universitas Udayana

Bendesa, I Gede. 2003. "Kumpulan Materi Mata Kuliah Pariwisata Berkelanjutan". Denpasar: Universitas Udayana.

Da Costa Fernandes, Rogerio.2012." Pengembangan Pariwisata di Gunung Tatamailau, Desa Nunomgue, Kecamatan Hatubuilico, Kabupaten Ainaro, Timor Leste (tesis). Denpasar: Universitas Udayana.

Damanik, Janianton., dan Weber, Helmut. F., (2006). Perencanaan Ekowisata. Yogyakarta.

De Carvalho, Deometrio do Amaral, do Carmo, Hortencio Pedro Fernandes Vieira, Cruz, Cristina, Samson, Gabriele 2008. Outro Mundo é Posivel Através Turismo Etico. Dili Timor Leste: Fundação Haburas

Dewi, Anita.2012. "Pengembangan Komponen Pariwisata Pancurendang Sebagai Kawasan Wisata Andalan di Kabupaten Majalengkan" (tesis). Bandung: Universitas Pendidikan Indonesia.

Fernandes, Quiteria Gisela Caitano.2013. Pengembangan pariwisata di Distrik Lautem Timor Leste. Universitas Udayana. 
Fiatiano, Edwin. 2012. Mengemas Produk Pariwisata pada Daerah Tujuan Wisata. Surabaya, Program Studi D3 Pariwisata Fisip Unair.

Inskeep, E. 1991. Tourism Planning - An Integrated and Sustainable Developmentt Approach. New York: Van Nostrand Reinhold

Karyono, A Hari. 1997. Pengertian Obyek dan daya tarik Wisata - Pariwisata Bali. [diunduh tanggal 10 November 2013].

Katrimin, I Wayan. 2010. "Strategi Pengembangan Pantai Berawa Sebagai Daya Tarik Wisata Berbasis Kerakyatan Di Kabupaten Badung" (tesis). Denpasar: Universitas Udayana

Kusuma Dewi, Luh Gede Leli. 2012. "Partisipasi dan pembangunan masyarakat Desa Beraban dalam pengelolaan secara berkelanjutan daya tarik wisata tanah lot" (tesis). Universitas Udayana

Lelo Taci, Antonio.2011. "Persepsi Masyarakat Terhadap Penerapan Upaya Pengelolaan Lingkungan”. Universitas Gadjah Mada Yogyakarta.

Mardikanto. 2003. Pengertian Partisipasi beserta tahapannya. Available from: URL: http://sacfirmansyah, wordpress.com/2009/06/05/ html.

Marpaung, . 2002. Pengetahuan Kepariwisataan. Bandung: Alfabeta.

Muljadi, AJ. 2009. Kepariwisataan dan Perjalanan. Jakarta: Raja Grafindo Persada

Parining, 2001. Studi Tentang Implementasi Konsep Pariwisata Kerakyatan. Denpasar : Bappeda Propinsi Bali dengan Universitas Udayana.

Paturusi, Syamsul Alam. 2008. Perencanaan Kawasan Pariwisata. Denpasar: Udayana University Press.

Pitana, I Gede dan I Ketut Surya Diarta. 2002. Apresiasi Krisis Terhadap Kepariwisataan Bali. Denpasar: The Works.

Pitana, I Gede. 2002. Konsep Pembangunan Pariwisata Berbasis Kerakyatan. [diunduh tanggal 10 November 2013].

Rangkuti, Freddy. (2002). Analisis SWOT : Teknik Membedah Kasus Bisnis. Jakarta: Gramedia Pustaka Utama

Rangkuti, Freddy. 2005. Analisis SWOT Teknik Membedah Kasus Bisnis Reorientasi Konsep Perencanaan Strategi Untuk Menghadapi Abad 21. 
Jakarta: Gramedia Pustaka.

Rero, Laurensius sandro 2011,Strategi pengembangan daya tarik wisata spiritual di kota Larantuka, Kabupaten Flores Timor Provinsi Nusa Tenggara Timor

Universitas Udayana

Soemarwoto, O. 2001. Paradigma baru Pengelolaan Lingkungan Hidup. Yogyakarta Gadja Mada University Suansri, P. 2003. Community Based Tourism. Bangkok, Thailand : Responsible Ecological Social Tours Project (REST).

Surya Wirawan, Gede Putu. 2009. Pengembangan Daya Tarik Wisata Bahari secara Berkelanjutan di Nusa Lembongan Kabupaten Klungkung," (tesis). Universitas Udayana

Suwantoro, Gamal. 2004. Dasar-Dasar Pariwisata. Yogyakarta: Andi Offset

TLS. 2010. Direcção Nacional de Estatistica (DNE/ BPS). Dili Timor Leste.

Wahyudi, Agustinus Sri. 1996. Manajemen Strategi. Jakarta: Binarupa Akasara.

Wardika Damayanti, Ida Ayu Kadek. 2009. Strategi Pengembangan Obyek dan Daya Tarik Wisata Pelabuhan Buleleng (tesis). Denpasar: Universitas Udayana.

Warpani, Suwardjoko P. dan Indira P. Warpani. 2007. Pariwisata dalam Tata Ruang Wilayah. Bandung: Institut Teknologi Bandung

Yoeti, Oka A. 1997. Perencanaan dan Pengembangan Pariwisata. Jakarta: Pradnya Paramita.

Yoeti, Oka A. 2006. Tours and travel marketing, cetakan kedua. Jakarta: PT Pradnya Paramitha. 